\title{
1. The Role of Patents in Innovation: Introduction
}

The topic of the role of patents in innovation is not new, rather, it is an old topic which has been debated for centuries by many scholars in many books and articles. This book does not intend to repeat what had been said in the existing literature, but attempts to add new findings to the existing stock of knowledge, and use these new findings to correlate or verify some of the existing conclusions. The new findings contain a central question which needs to be answered, that is: do patents promote innovation in biotechnology and pharmaceutical industries in China? This is a country which is largely different from most countries in the world as it is the largest developing country; a transitional economy with a strong public element, and the world's fourth-largest economy with relatively high technological capacity. Phrasing this question in another way: how do patents' role in China's biotechnology and pharmaceutical industries differ from their role in those industries in industrialized and other developing countries? The new findings will be derived from a thorough research into biotechnology and pharmaceutical patenting in China in later chapters: its technological background, legal standards, and empirical data analyses of patent applications and litigations, and so on. However, these findings will be of little meaning unless compared with the existing literature on the topic. Therefore, an introduction of existing debates in this chapter on the role of patents in innovation, including the debates about patent's role in industrialized countries and in developing countries, will serve as a theoretical foundation for the discussions of the new findings about the patent's role in China later on. In the meantime, to help readers understand the justifications and significances of some events, facts and legal issues discussed in later chapters, this chapter also provides background information on how the issue of patents and innovation was raised and what are the laws and policies concerning patents and innovation in China. 


\section{BACKGROUND AND QUESTIONS}

\subsection{National Laws, Policies and Strategies Concerning IP and Innovation}

The beginning of the twenty-first century has marked a new era for China, an era in which China has embarked on a journey of transformation from an imitation-oriented country to an innovation-oriented country. This transformation process is evidenced by a series of national plans issued by the Chinese government in recent years. On 9 February 2006, China held the National Science and Technology (S\&T) Summit and issued the Outlines of National Medium and Long Term S\&T Development Plan (2006/2020) (S\&T Development Plan), which set the goal of advancing China into an innovation-oriented country by 2020 . According to the plan, an 'innovationoriented nation' means that by 2020 , China will invest more than 2.5 per cent of its GDP in R\&D; the contribution rate of S\&T progress to economic development will exceed 60 per cent; and the dependency ratio for foreign technologies will decrease to below 30 per cent. Furthermore, the number of China's indigenous invention patents and number of its SCI papers are expected to rank among the top five countries in the world. The way to achieve this goal is to enhance indigenous innovation, especially with regard to creating and producing intellectual property rights (IPRs).

To realize the above goals, the Chinese government has passed a series of legislation and policy documents. On 5 June 2008, the State Council officially released a notice to publicize the 'Outlines of National Intellectual Property Strategy' (Outlines 2008). Some of the strategic goals set out in the Outlines replicate those in the S\&T Development Plan, that is, to transform China into an innovation-oriented country, to increase its annual patent filings to become among the top five countries in the world in terms of patents, and to increase the number of overseas patent applications from Chinese applicants. ${ }^{.}$Once again, a nexus between intellectual property and innovation was made. The preface of the Outlines 2008 states:

Implementing the national intellectual property strategy to greatly promote China's capacity in creation, protection and administration of intellectual property will help improve China's capacity for independent innovation and aid in efforts to make China an innovative country (Outlines 2008).

On 29 December 2007, the Standing Committee of China's National People's Congress (NPCSC) revised 1993 Science and Technology Progressing Law (S\&T Law). ${ }^{2}$ The majority of the revised articles concern the theme of 
innovation and intellectual property. For example, Article 2 of the revised law explicitly states that the state plays a leading role in creating an innovative infrastructure and building an innovation-oriented country, and Article 7 stipulates that the state designs and implements IP strategies and perfects the IP system. One of the most important amendments made to this law is Article 20 allowing researchers or institutions undertaking state-funded S\&T projects to own the following IPRs: patents over inventions; copyright over computer software; design rights over layout designs for integrated circuits; and plant variety right over new plant varieties, except those projects relating to national defense, national security and important public interests. ${ }^{3}$ This article is important because, first; it changed a long established tradition based on a centrally-planned economy that any IPRs derived from statefunded projects automatically belonged to the state. This amendment may consequently provide more incentives for innovation; secondly it helps to alleviate the disappointment many people felt for the amendment of the Patent Law which failed to give IPRs derived from state-funded projects to researchers or institutions undertaking the projects (although this may have created inconsistency between the two laws). ${ }^{4}$

One year later following the enactment of the S\&T Law, on 27 December 2008, the NPCSC endorsed the third amendment to the Chinese Patent Law which was originally enacted in 1984, after the first amendment in 1992 and the second amendment in 2000 . The first two amendments were undertaken largely under external pressure to elevate China's patent protection level up to the expectation of some developed countries such as the United States or international standards such as Agreement on Trade-Related Intellectual Property Rights, or TRIPS. The third or the latest amendment, on the other hand, was conducted almost entirely under China's internal initiatives based on the government's policy shift from attracting foreign investment and technology transfer to protecting indigenous innovations and transforming China from an 'imitation-oriented country' to an 'innovation-oriented country'. More specifically, the main objective of this round of amendments included implementing a new national strategy to make China an 'innovationoriented country', balancing the interests of patent right holders and the public, preventing patent right abuses, and harmonizing Chinese patent law with international patent norms. Article 1 of the amended Patent Law makes it clearer than the original law that one of the purposes of enacting the new law is to 'promote innovative capacity'. What is worth noting is that all earlier drafts of the amendment contained the words 'construction of an innovative country' in Article 1, but these words were taken out from the final amendment which was passed by the NPCSC. The reason for this 
change is not clear, but the words 'promote innovative capacity' still clearly sent out a message that the main purpose of this round of amendments was to fulfill the government's policy of making China an 'innovation-oriented country' in the next decade. The amendment also addressed another controversial issue, that is, whether individuals or institutions undertaking state-funded projects ought to be allowed to own IPRs derived from the projects. The issue was heatedly debated during the amendment process because it concerns whether IPRs can be used as an incentive to stimulate innovation. However, as mentioned above, the amended law disappointed many people who had hoped for a positive answer to the question. Nevertheless, several other amendments were adopted with the objective of promoting innovation. They are: (1) clarifying patent right ownership; (2) changing patentability criteria from a mixed to 'absolute' test; (3) making the use of compulsory licensing more extensive; and (4) preventing patent right abuse and introducing 'Bolar exception'. These changes are discussed in Chapters 6,7 and 8 in relation to the biotech and pharmaceutical industries.

\subsection{Research Questions}

It is interesting to note that China, after having comfortably enjoyed more than two decades of economic boom largely by acting as a worldmanufacturing center and by imitating or 'free-riding' on Western technological advances, has now embarked on a journey of self-innovation. More interesting still is that the Chinese government has made a connection between innovation and IPRs, particularly patents, believing that an increase in patent filing would mean an increase in the nation's innovations. This belief is probably based on a view that intellectual property rights are a source of incentive for innovation which can promote innovative activities and can thus turn China from an imitation-oriented country to an innovationoriented country, which is popularly adopted among Chinese government officials and academics alike. ${ }^{5}$ Some state-funded research projects have been carried out and most of the research results are supportive of this view. ${ }^{6}$ What has prompted the Chinese government to shift its policy orientation from imitation to innovation? Why would the Chinese government make a connection between patents and innovation? Are there any theoretical analyses or empirical evidence to support such a connection? If a connection does exist between patents and innovation, or in other words, if patents do play a role in innovation, do they play the same role in China as they play in industrialized countries? Or more specifically, does acquiring more patents mean achieving more innovations, as the Chinese government and many Chinese scholars appear to believe? These issues are puzzling for IP 
specialists studying the role of patents in innovation and for China specialists following trends in China's S\&T development.

An even more puzzling phenomenon in China is that, by the end of 2007 , the total number of patents filed in China has reached four million, ${ }^{7}$ and by March 2009 , this number reached five million, ${ }^{8}$ internationally ranking China third behind the United States and Japan. Among the first four million, domestic filings accounted for more than three million, or more than 80 per cent of the total patent applications filed (S1PO 2007). In spite of this astonishing stock of patent applications, however, no one in China or elsewhere has deemed China as an innovative country. In fact, the prevailing view is that China is still a largely imitation-oriented country with its industries based on low-cost manufacturing. This view is supported by various facts: 99 per cent of Chinese companies have never applied for patent applications, 60 per cent of them have no trademarks of their own, and merely three out of 10000 Chinese enterprises own IPRs. ${ }^{9}$ If the vast majority of Chinese enterprises are not filing patents, who is filing these three million patents? And perhaps more importantly, if the very high number of patents filed does not make China an innovative country, does this mean that the role of patents in promoting innovation is only a myth and that the Chinese government is mistaken or being misled in believing that the higher the number of patents a country files, the more innovative it becomes? Yet, if the number of patents filed is not related to innovation, why do the most innovative countries in the world, such as the United States, Japan and Germany, have the highest numbers of patent filings (for example, the annual patent filings of Japan, the United States and Germany are 40000,20000 and 15000 , respectively)? What are the differences between the patents filed in these countries and those in China? In other words, what kinds of inventions have been filed for patent protection in China? Do they contain highly innovative components, or are they all 'junks'? Who are filing patents in China and why they are filing? Is it possible that patents are filed for the sake of filing, due to government's pressure to make China one of top five countries globally in terms of patent filing?

In addition to the quantitative and qualitative aspects of patent applications, one may also wonder whether patents, after being granted in China, are exploited and commercialized into marketable products, and whether patents are maintained or abandoned shortly after they are granted. Without commercialization, or if patents are not maintained or only maintained for a very short period of time, the value of patents will not be fully realized. Furthermore, inventions without commercialization are not considered as innovation. According to Mark Roger, invention concerns the 
generation of a new idea or knowledge while innovation concerns the commercialization of those new ideas (Roger 1998). Only when an invention has been commercialized can it be called 'innovation'. Similarly, Schmookler defines invention as a new way of producing something old or an old way of producing something new, while innovation was the first use of an invention (Schmookler 1966). Could this differentiation partly explain the peculiar situation in which China has a very high patent filing and granting rate but cannot be categorized as an innovative country, because China has primarily focused on invention rather than commercialization? If this assumption is correct, would it be appropriate to say that the Chinese government is right in connecting patents with innovation, but falls short in recognizing that innovation entails not only the sheer number of patents that are filed but also the large number of patents that are commercialized? These questions carry tremendous importance in understanding the real role of patents in innovation and whether China can successfully transform itself from an imitationoriented country to an innovation-oriented country by promoting the role of patents.

To analyze and answer the above questions, this book has chosen the biotech and pharmaceutical industries as case studies because the biotech industry has been identified as one of the foremost important fields in China's S\&T development. ${ }^{10}$ Biotech was listed as the first among eight frontier technologies identified by the S\&T Development Plan. ${ }^{11}$

On 2 June 2009, China's State Council issued a notice on 'Several Policies Concerning the Promotion of Speedy Development of Biotechnology Industry' (Biotech Policy). The preamble of the notice declares that:

Incubation of biotechnology industry is the state's most important strategy to grasp the strategic opportunity of new technological revolution in the new era and to build an innovation-oriented country. It is the objective of this notice to implement the 'Outlines of National Medium and Long Term S\&T Development Plan $(2006 / 2020)$ ' as well as 'The 11th 5-Year Program for the Development Biotechnology Industry', and to quickly incubate biotechnology industry into a pillar industry in the high-tech area as well as the state's strategic industry.

In order to achieve the above goal, the notice identified four specific policy objectives including: (1) orienting research resources - technology, talents and money - towards the biotech industry; (2) building an innovative structure which consists mainly of industry, market, and collaborations between industry and research institutions; and strengthening innovative capacity in order to possess important biotechnology products and standards which can derive IPRs; (3) incubating several multinational biotechnology companies and a large number of small and medium enterprises (SMEs) 
possessing innovative capacity and IPRs; and enabling a number of highly concentrated, competitive, and distinctive biotechnology industrial bases to emerge; and (4) strengthening patent protection for biotechnology and the protection for biodiversities. The Biotech Policy also identified five key biotech areas to be developed: biomedicines, bio-agriculture, bio-energies, bio-manufacturing, and bio-environmental protection. Among these five areas, bio-medicine research will focus on new vaccines and diagnostic kits for the prevention and diagnosis of the major infectious diseases which threaten the Chinese public; bio pharmaceuticals, small molecule medicines and modern traditional Chinese medicines (TCM) which have proven effect treating common and serious diseases; biomedical materials, tissue engineering, organ transplantation and clinical diagnosis and treatment equipment; and R\&D outsourcing. The rest of the Biotech Policy suggested many strategies to achieve the policy objectives such as increasing financial support, promoting international cooperation, attracting overseas talent, and creating conducive conditions for technology transfer and commercialization. It is noticeable that intellectual property was mentioned repeatedly in the document, for example, speeding up biotech-related IP examination in order to encourage the biotech industry to acquire and commercialize IPRs (Articles 16, 17, 20); including patented bio pharmaceuticals in the list of national medical insurance (Article 25); and perfecting IP protection and enforcement for biotechnology (Article 27).

This book uses the biotechnology industry as a case study to illustrate the role of patents in the process of transformation of China from an imitationoriented country to an innovation-oriented country, and also because the current Chinese biotech industry was characterized as at a point of transformation from 'follow-and-copy' the West to 'begin to innovate' by the China National Center for Biotechnology Development (CNCBD) under the Chinese Ministry of S\&T (MOST) (Tang 2004). Therefore, the biotech industry provides the best case study to view the processes of transformation. The pharmaceutical industry is being included in this study because it is closely allied with the biotech industry and heavily dependent on biotech as a platform for drug discovery. ${ }^{12}$ This book intends to use the interplay between patents and the biotechnology ${ }^{13}$ and pharmaceutical industries to demonstrate the current status of China's S\&T development and to show how these industries have been stimulated and protected by patents in order to analyze the possibilities of China's transformation from an imitation-oriented nation to an innovation-oriented nation with the help of the patent system. 


\section{THE THEORETICAL DEBATES ON THE ROLE OF PATENTS IN INNOVATION}

To answer the question of what role patents play in innovations in China's biotechnology and pharmaceutical industries, a review of the theoretical debates on the role of patents in innovation in general will be helpful in providing a fuller picture and eventually making a more objective judgment on this issue. This section starts with the debates on the role of patents in industrialized countries, followed on by an introduction to the literature on the role of patents in developing countries.

\subsection{IP and Innovation: Debates Concerning Industrialized Countries}

The relationship between patents and innovation has been a subject of debate among IP scholars since the birth of the patent system. The central theme of debate is whether IPR, or patents in particular, can promote innovation. The views, based on the answers and analyses given to the question, are roughly divisible into three kinds: positive, negative and mixed. The positive view about the role of patents in innovation believes that patents can promote innovation because the monopoly provided by patents allow inventors to recoup the costs of their inventions and to invest in further research, and the disclosure required by the patents encourages dissemination of new technology. The negative view about the role of patents in innovation concludes that patents may impede innovation because monopolistic rights give patent holders exclusive control over technologies, thereby impeding competition and creating obstacles to innovations by others. The mixed view about the role of patents in innovation, on the other hand, does not completely side with any of the above two opposing views. Rather, the evaluation of the role of patents, whether positive or negative, is based on the analyses of the fields of technology, the stages of research with which patents are concerned, or the social and economic conditions of different countries. Typically, as shown later in this section, some scholars see patents for biotechnology and pharmaceutical innovations as positive or necessary stimuli, but consider them unnecessarily broad and extensive for information technology. Even within one industry, for example, biotechnology, the role of patents is judged differently. For example, many scholars believe that patents for upstream research or research tools in bio-medical field blocks downstream research. The following discussion provides a more detailed account of how the above different views started and evolved. 
Debates on the role to innovation can be traced back to the debates on whether patent rights are justified. John Locke's natural right theory argues that an individual has the right to the fruits of his labor, and utilitarian theory argues that when people are rewarded for their work, they have more incentive to produce more. Specifically on patents, when an inventor is rewarded patent rights for his invention, he is supposed to have more incentive to create more inventions. In 1962, Arrow took this argument further based on economic analyses of IPRs. According to his theory, knowledge became a 'good' when it was assimilated as information and hence was subject to property ownership. However, the 'indivisible' nature of knowledge created the following problem. While the first creator of a certain technology had to invest a huge amount of financial and human resources, the subsequent production might cost very little or nothing at all, creating the so-called 'free-rider' phenomenon. This further led to 'underinvestment' in knowledge production because no one was willing to become the first inventor. Since the market itself was not able to solve this problem, certain 'institutional arrangements' had to be put in place. The patent system together with public subsidies composes such an institutional arrangement in order to grant a temporary monopoly to the first inventor to help him or her to recoup any investments (Benjamin Coriat, Fabienne Orsi and Cristina d'Ameida 2006). Hence the establishment of an IP system is to remedy 'market failure' and serve as an 'incentive-by-award' system to encourage innovation. Based on this premise, the role of IPRs is seen by many scholars and practitioners as largely positive. Dutton succinctly summarized the views of some of these scholars:

Holdsworth, for example, claims that during the late seventeenth and eighteenth centuries 'the administration of the law as to the grant of patents ... was successful in encouraging British industry'. Fox considered that 'it was ... not by accident that the patent system had its origins in England nor that the Industrial Revolution was the inevitable consequence'... In a much neglected book Ravenshear argues that 'patents exercised a net influence in stimulating the growth of industry'. For Harding there was 'little doubt that patents helped to create the industrial supremacy which existed at the time of the Great Exhibition'. And Hatfield, writing in a mood of patriotic zeal, concluded that the 'patent law was our invention, and it gave us the first place among nations in industry for over 200 years' (Dutton 1984, p. 3).

Furthermore, Barton and Emanuel (2005) state that the patent is a genius design for the recognition of an inventor's creativity and a means to enhance innovation. Burk and Lemley (2003) confirmed that 'patent law is a primary 
policy tool to promote innovation, encourage the development of new technologies, and increase the fund of human knowledge'. Comish and Llewelyn observe that 'it is very difficult to measure or assess the effects (if any) that a patent system is producing', nonetheless, they recognize that 'there is no clear evidence that corporations are not influenced in their research and development decisions by their chances of securing and taking advantage of patent protection', though they caution not to ignore the 'individual inventor' in assessment of patents (Comish and Llewelyn 2007, p. 135). Greenhalgh and Rogers (2007) list four ways in which IPRs can promote innovation. First, people will have more incentive and resources to innovate by having a monopoly on their innovations. Second, venture capitalists are more willing to fund a project that has patent protection. Third, firms may invest more in R\&D using profits gained from IPRs through licensing and various patent strategies. And finally, the early disclosure of patent technology enables the dissemination of technological information. This list nearly mirrors the reasons for supporting the patent system given in the US 'Report of the President's Commission on the Patent System 1-3' (1966). That report states:

\begin{abstract}
Agreeing that the patent system has in the past performed well its Constitutional mandate 'to promote the progress of ... useful arts', the Commission asked itself: What is the basic worth of a patent system in the context of present day conditions? The members of the Commission unanimously agreed that a patent system today is capable of continuing to provide an incentive to research, development, and innovation. They have discovered no practical substitute for the unique service it renders. ${ }^{14}$
\end{abstract}

Particularly in the biotech and pharmaceutical industries, patents are considered important for new spin-off and start-up enterprises to attract capital investments and to use as negotiating tools in joint ventures and alliances. 'Even public research organizations are placing more strategic value on patenting', said a report written by a group of researchers from the Canadian Program on Genomics and Global Health (Quach et al. 2006). Chambers compares the biotechnology patenting regimes in the United States, Europe and Japan and reaches a conclusion that:

The United States has capitalized its strong biotechnology research base and broad concepts of patent-eligible subject matter to lead the world in biotechnological research and development ... Just as developing countries can accrue a temporary free-rider advantage by providing minimal patent protection, Europe and Japan have limited their patent protection in those biotechnological areas that trail the United States. While such limited patent protection provides short-term benefits, it also runs the risk of locking Europe and Japan into long-term position of technological 
inferiority by failing to adequately protect research and development investments in biotechnology (Chambers, 2003 p. 225).

On the other hand, many scholars are not convinced by the above assessments. They are skeptical or even critical of the role of the patent system in innovation. For example, Boehm and Silberston said that patents were largely irrelevant as a means of inducing inventions, and that some other stimuli 'must have been responsible for the inducement of a large body of nineteenth century invention' (Boehm and Silberston 1967, p. 37). A similar conclusion was reached by Ashton (1968) and Landes (1970). Schiff studied inventive activity in Switzerland and The Netherlands during the period that the two countries abandoned their patent system and concludes that the 'industrialization of a country can proceed smoothly and vigorously without a national patent system' (Schiff 1971). Blakeney finds that the 'assumption that patent protection incentivises innovation has never been convincingly demonstrated, even in industrialized countries, although it underpins the globalized intellectual property regime' (Blakeney 2009, p. 240). As to whether patents' benefits outweigh costs, Machlup concludes that 'no economist on the basis of present knowledge could possibly state with certainty that the patent system, as it now operates, confers a net benefit or a net loss upon society'(Machlup 1959, p. 79). Maskus (2003) believes that the conclusion that stronger IPRs influence foreign investment, licensing behavior and the transfer of technology can only be tentatively reached because the data and methodology of research to support such conclusion are very weak.

In addition to the above two contrary views, some scholars believe that the role of patents in innovation varies by context. Specifically, they argue that the role of patents is specific to certain industrial sectors, types of technology, and stages of innovation. Hall (2007) provided theoretical and empirical evidence on this finding. According to him, some earlier studies show that when patents are granted to single products or pieces of knowledge, it is almost certain that the patent will encourage innovation. In some instances, the patent may produce 'too much' innovation. Yet, when the patent involves multiple products, many pieces of knowledge or multiple stages of research (such as 'research tools' in upstream medical research and downstream drug discovery), or the innovation is sequential or cumulative, then the role of patents in innovation may be positive in some contexts but negative in others. Bessen and Maskin (2006) conclude that there are more innovations without patents in sequential cases. Others found that patents are only positively associated with innovation in the pharmaceutical, biotech, and medical 
instrument areas (Mansfield 1986; Levin et al. 1987, Arora et al. 2001; Cohen et al. 2002). However, Heller and Eisenberg (1998) reached a conclusion that patents for upstream medical research can deter innovation. They state, ' $[P]$ roliferation of fragmented and overlapping' patent rights creates a tragedy of 'anti-commons in which people under-use scarce resources because too many owners can block each other.' Based on the studies of genomic diagnostics, Barton discovered that patents for devices such as the oligonucleotide chip which is used for sequencing, seeking mutations, testing pathogens to evaluate different forms of drug resistance and testing cancer cells to determine the specific mutation involved, 'raise no problem of excluding others from detecting the same mutations in different ways; they almost certainly serve as useful incentives to develop new technologies'. But patents for 'the use of a specific gene sequence to identify a specific biological property (that is, patents on specific diagnostic sequences or on pathogen or cancer-related mutations) pose a particular problem', because 'they may make it difficult for the integrator of a microarray/chip device to assemble the rights to use the different patented sequences that are relevant to a clinical or research application' (Barton 2006, p. 939).

Due to the diverse role of patents among various technologies, scholars have developed theories about whether a patent right, or how much of a patent right, should be given to inventions produced in different industrial sectors and stages of research. In 1977, a 'prospect theory' was developed by Edmund Kitch, who argued that patents encourage further commercialization and more efficient use of unrealized ideas, just as a 'prospect' system encourages a landowner to make efficient use of his or her private land. As such, strong rights should be given to a single entrepreneur. The 'patent should be broad, stand alone, and confer almost total control over subsequent uses of the product' (Kitch 1977). In 1990, the theory of 'tailored incentives' was developed by Robert Merges and Richard Nelson, based on the 'cumulative innovation' model. According to this theory, since innovations are cumulative, patent rights should be granted to both the initial inventor and subsequent improvers so that an incentive to innovate can be fairly maintained (Merges and Nelson 1990). In 1998, an 'anti-commons' theory emerged to adjust the 'tailored incentives' theory by pointing out that patents that horizontally cover different species as well as vertically protecting different steps will render resources in the commons underused because patent owners can block each other. To solve this problem, the patents should be either consolidated into a single hand or be eliminated altogether for certain types of innovations, for example, upstream research tools (Heller 1998). Barton also proposed two possible ways to limit patent rights to 
diagnostic sequences: one is to reject patent coverage, and another is to require patentees to grant reasonable-royalty licenses for use of the sequence as a part of an array or for use of the sequence in pharmacogenetics (Barton 2006).

Building on the above theories, Burk and Lemley (2003) proposed an 'industry-specific theory' to see how these theories best fit various industries so that the role of patents in innovation can be maximized. They found that industries vary greatly in terms of innovation, and each of the above theories may fit better in one kind of industry but not another. For example, 'cumulative innovation theory' fits best in business methods, software, and arguably Internet industries, while 'prospect theory' fits best with the pharmaceutical industry. Specifically, 'prospect theory' can be used to justify strong and broad patent rights granted to the initial inventors in the pharmaceutical industry because:

1. the pharmaceutical industry normally has long development and testing lead times;

2. it is very expensive to innovate, for example, US $\$ 800$ million on R\&D for each new drug;

3. its products are easy to imitate, and generic producers can avoid R\&D cost entirely;

4. if a patent does not cover a group of related products, imitators can easily design around the patent by using a close chemical analog; and

5. much of the work occurs after the drug is first identified, so it is important to give patentees the right to coordinate downstream changes to the drug.

In the same vein, 'anti-commons theory' can also be used to support strong and concentrated patent rights in the biotech industry because, similar to the pharmaceutical industry, biotechnology is a high-cost and high-risk industry. But on the other hand, attention has to be paid to the 'anti-commons' problem caused by patenting upstream research tools. Based on these analyses, Burk and Lemley concluded that patent law should not be uniformly applied across different industries; instead, various policy levers of patent law should be applied by courts to accommodate the specific nature of different technologies and industries. For example, within the pharmaceutical industry, fewer and broader patents should be granted with more relaxed disclosure requirements and strengthened doctrines of equivalents. Within the biotech industry, there should likewise be fewer and broader patents with more 
relaxed written enablement requirements as well as strengthened doctrines of equivalents and experimental use exceptions.

\subsection{IP and Innovation: Debates Concerning Developing Countries}

The above theories are largely focused on industrialized countries. Though disputed, the role of patents in developed countries are largely viewed necessary and positive, with some disagreement on exactly how important the patent is in different industrial sectors (CIPR 2002, p. 13). The question now is, do patents play any role in innovation in developing countries at all, and if so, is the role similar or different from their role in the developed countries? Grundmann's study shows that 'by far the most efficient way for developing countries (and also industrialized countries) of encouraging the production of new technology is an increase in education in the technical and science field and not law on the protection of inventions' (Grundmann, 1970, at 198). Braga (1990) found 'there is very little empirical evidence of the impact of stronger intellectual property protection on domestic R\&D in developing countries'. Other studies found that the strength of IPRs is positively associated with R\&D investment in countries with above-median income but not for less-developed countries (Park and Ginarte 1997). The UK Commission on Intellectual Property Rights reached similar conclusion in its report,

for most developing countries with weak technological capacity, the evidence on trade, foreign investment, and growth suggests IP protection will have little impact ... For more technologically advanced developing countries, the balance is finer. Dynamic gains may be achieved through IP protection, but at costs to other industries and consumers (CIPR 2002, p. 4).

In addition, the report specifically pointed out that the "IP system hardly plays any role in stimulating research on diseases particularly prevalent in developing countries' (CIPR, 2002, p. 5).

However, other studies on biotechnology industries in developing countries have proven that the connection between patents and innovation does exist in developing countries. In a recent study on genomic medicine in countries such as Mexico, India and Thailand, the researchers identified the inadequacy of existing regulatory and intellectual property regimes in these countries as one of the significant obstacles to advances in genomics (Seguin, et al. 2008). They further concluded in their report that, "in health biotechnology, intellectual property protection remains a vital factor towards the establishment of a private sector and the commercialization of products in 
developing countries'. Another study on Brazil's biotech industry identified an inefficient patenting system as one of the four major barriers to bio-health development. Specifically, Brazilian patent law does not protect some important bio technologies, such as recombinant version of proteins found in nature, and it takes a very long time (more than seven years) to process patent applications for drug candidates (Rezaie, et al. 2008). Furthermore, a study on India's biotechnology industry points out that Indian firms aim to become more competitive by patenting their products and technologies on a global basis (Frew, et al. 2007). One specific example of how a patent system has become a driver in India's health biotechnology was found in the study by Seguin et al. mentioned above (Seguin, et al. 2008). Shantha Biotechnics Private, a spin-off company from Osmania University in Hyderabad, India, has leveraged its patented innovative manufacturing process in the Pichia Pastoris expression system to produce a recombinant hepatitis $\mathbf{B}$ vaccine. Professor Joseph Straus (2007) also attributed the recent growth of India's pharmaceutical sector to a stronger patent regime India adopted in compliance with the TRIPS, for example, by achieving TRIPS protection standards in pharmaceutical patent protection. In addition, other developing countries are also strengthening IP protection for their health biotechnologies. For example, the Mexican National Genomic Medicine Institute (INMEGEN) and the Mexican Institute of Intellectual Property (IMPI) have formed a strong collaboration to share expertise, and together they are negotiating for a $\$ 5$ million grant to enable INMEGEN to maintain an in-house IP office through which Mexican researchers can be assisted in acquiring patents for their research. Thailand's health biotech industry, through the TCELS Pharmacogenomics Project, also works closely with the Department of Intellectual Property at the Ministry of Commerce to protect its IPRs.

China is the largest developing country. In the meantime, China is also a country with relatively high technological capacity as identified by CIPR report. According to the report, technological capacity is determined based on the extent of patenting activity in the United States and through the Patent Cooperation Treaty (PCT) (CIPR 2002, p. 13). In 2007, Chinese filed 4141 patent applications with the US Patent and Trademark Office (USPTO). ${ }^{15}$ In 2008, China's PCT applications reached 6089 , ranking China No. 6 among all other countries for PCT filing. ${ }^{16}$ These figures demonstrate that China is a developing country with relatively high technological capacity. CIPR's report concludes that patents play different roles in more technologically advanced developing countries than in technologically weak developing countries in that it responds to innovation activities more positively in the former. The findings on what role patents play in China's innovation in biotech and 
pharmaceutical industries, therefore, can be used to complement, corroborate, or verify CIPR's conclusion, as well as the research results concerning the role of patents in developed countries and developing countries introduced above.

Currently, there are a growing number of studies on China's biotech and pharmaceutical industries, including their market scale, R\&D trends, and commercialization. ${ }^{17}$ There are also emerging studies on China's biotech and pharmaceutical patenting. ${ }^{18}$ However, these two areas of studies are not well connected or integrated, or in other words, the link between the study of industry and technology and the study of patent systems is fairly weak. For example, some of the studies are fairly comprehensive regarding the scale of China's biotech and pharmaceutical industries, but they contain no or very little information on how these industries deal with the patent issues and how patents have affected the development of these industries. Likewise, other studies only focus on the technicalities of biotech patenting without analyzing them in the context of industrial scale, R\&D infrastructure and market. A few studies appeared recently trying to analyze the role of patents in China's technology and industrial context. For example, Joseph Straus (2007) uses the increase of patent applications, R\&D expenditures, and foreign factories and R\&D labs to make a point that IPR protection played a decisive role in China's economic growth. Similar research was carried out by Grace Cheri (2004). However, these studies are still not comprehensive and systematic enough, and are short of theoretical analysis and convincing empirical data. This book attempts to follow on this kind of study. Through an empirical analysis of the development of the Chinese biotech and pharmaceutical industries and their $\mathrm{R} \& \mathrm{D}$, commercialization and patenting trends including patent filings and litigation, this book intends to explore what role patents play in a developing country's biotechnology and pharmaceutical industries which is in the process of transforming from imitation to innovation, and whether this role is similar to that in the industrialized countries. The findings of this study may contribute to the existing theoretical debates on the role of patents in innovation and help IP scholars and policymakers in China make sound choices and judgments in reforming China's patent law and policies.

This book is divided into nine chapters. In addition to this chapter, which provides an overall theoretical background and introduces the central theme of this book, Chapter 2 provides general background about China's biotech and pharmaceutical industries to lay a foundation for the later chapters. Chapter 3 surveys China's current innovative capacity in the biotech and pharmaceutical industries so that an objective assessment can be made as to the role of patents in innovative activities. Chapter 4 further explores models and strategies for innovation and commercialization as well as the role of 
patents in these models. Chapter 5 empirically analyzes the numbers and types of patents filed by China's biotech and pharmaceutical enterprises as well as the various patent disputes in litigation to evaluate whether patents can affect innovation. From Chapter 6 to Chapter 8 , the book turns to Chinese patent law to systematically analyze relevant provisions governing biotech and pharmaceuticals to ascertain whether they are appropriate to encourage and protect innovations in biotech and pharmaceutical industries. Specifically, Chapter 6 discusses patentable biotech and pharmaceutical inventions; Chapter 7 focuses on patentability criteria such as novelty, nonobviousness and utility; Chapter 8 discusses how patents involving biotech and pharmaceutical inventions are protected in China. In these chapters, new amendments to the patent law involving biotech and pharmaceuticals are mentioned and related to questions of whether they are conducive to China's endeavor to become innovation-oriented country. Chapter 9 summarizes the major points in the preceding chapters and further reflects on the role of patents in promoting China's innovation strategy. The book concludes that patents are indispensable to promote innovation in present China, a developing country with relatively high technological capacity but with low innovation output, particularly when the patent system is still largely underused in the sense that the majority of Chinese enterprises fail to appreciate the value of patents, that the numbers of foreign filing and PCT filing are still relatively small compared with many of the developed countries, and that the quality of patents is also fairly low. On the other hand, this book also recognizes that the ultimate goal of innovation is to promote science and social welfare, and that it is important for China to achieve a fair balance between the promotion of patent rights and the need to access technologies and medicines, and to leam the lesson from other industrial nations about how to use patents to stimulate innovation and how to avoid public health and other social and public policy problems caused by the abuse of patent system.

\section{NOTES}

1. The outlines start with the following phrase: 'this outline is formulated for the purpose of improving China's capacity to create, utilize, protect and administer intellectual property, making China an innovative country and attaining the goal of building a moderately prosperous society in all respects'. Outlines of National Intellectual Property Strategy, Article 2(7), "Goals for the next five years', accessed; www.nipso.cn/gnwzscqux/qtipdtt200 80621_98086.asp.

2. The revised law takes effect on 1 July 2008 . 
3. The IPRs concerning these projects must be exploited within the term of the IPRs, otherwise the state can exploit or permit others to exploit without compensation to the rights holders. Article 21 also 'encourages that the IPRs derived from the state funded projects be exploited first within the territory of China ... If the IPRs are to be transferred with exclusive licence to foreigners, the transfer must be approved by managing authority of the project'.

4. See Chapter 8, section 1.2 of this book.

5. For example, the Director of China's State Intellectual Property Office (SIPO) Mr Tian Lipu said that IP is the foundation and benchmark of self-innovation and an important tool for China to implement its innovation and development strategy. See Guangming Daily, February 19, 2006, accessed: www.gmw.cn/0lgmrb/2006-02/19/content_376159.htm.

6. For example, a project on 'Innovation and Intellectual Property' carried out by the Beijing University School of Intellectual Property.

7. This figure rose to 4853506 by the end of 2008 .

8. SIPO Management and Development Bureau, 'Patent applications reached five million', Patent Statistics, 23 March 2009, No. 7, accessed: www.sipo.gov.cn/sipo2008/ghfzs/zltijb/20 0903/P020090330379382318864.pdf.

9. For details, see 'Enterprise IPRs and building innovation-oriented country', China Industry Daily, January 30, 2007, accessed: www.nipso.cn/qyyzscqzlyj/200805/20080507_397833.h tmi.

10. As Mr Jin Ju, Head of Chinese Delegation, said at the Meeting of 5th Session of United Nations Commission on S\&T for Development, 'life science and biotech is of great importance to China. The Chinese government attaches much attention to the development of modem life sciences, as we believe that biotech will help us to solve the most urgent problems, such as population, food supply, health care and environment protection'. Jin Ju, 'Life Science and Biotechnology in China', Speech at the Meeting of 5th Session of UN Commission for Development' (28 May-1 June 2001, Geneva, accessed: www.chinaun.ch/eng/zmjg/jgthsm/t85522.htm.

11. The other seven frontier technologies are: information technology, new material technology, advanced manufacturing technology, advanced energy technology, marine technology, laser technology and space technology.

12. Specifically regarding biotech and pharmaceutical industries, China has identified the following areas deserving the foremost attention and requiring major breakthroughs in the prescribed period: functional genomics and proteomics, molecule design and structuring for drugs, animal and plant varieties, research on biochips, stem cells and tissue engineering, and therapeutic cloning. This book will deal with most of the above technologies in China and related $R \& D$, commercialization and patenting status.

13. The term 'biotechnology' used in this book means modern bio technology. While traditional biotechnology refers to the technology based on selective breeding technique, modem bio technology largely refers to the technology based on genetic engineering, namely, products consisting of DNA sequences and micro organisms derived from a lab using recombinant techniques and that have a proven utility not found in a natural state.

14. Report of the President's Commission on the Patent System, 1-3 (1966).

15. SIPO Management and Development Bureau, 'Huge increase in filing invention patent applications in foreign countries in 2007', Patent Statistics, 29 February 2008, 5 November, accessed: www.sipo.gov.cn/sipo2008/zltijb/200804/t20080421_387141.html.

16. The other five countries are: the U.S., Japan, Germany, South Korea, and France. See SIPO Management and Development Bureau, 'China's PCT application ranks No. 6 in the world in 2008', Patent Statistics, 5 February 2009, No. 2, accessed: www.sipo.gov.cn/sipo2008/gh fzs/zltjjb/200903/P020090302609583592440.pdf.

17. Represented by the annul report of Chinese government on China's bioindustry (2006); book published by Lian Ma and R.D. Schmid (2003), Chinese Bio Today, Shanghai: Printing Center of the General Office of the CPC Shanghai Municipal Committee; Report by 
Boston Consulting Group (2005). 'A Game Plan for China: right sing to the productivity challenge in biopharma R\&D', $B C G$ Focus, accessed: www.bcg.com; and a series of reports on China's biopharma industry by E. Y. Zhou of Bio Pharma International.

18. For example, there are several books on China's biotech and pharmaceutical patenting, including Zhang Qingkui, Writing and Examination of Patent Applications for the Inventions in the Fields of Medical. Pharmaceutical and Biotechnology (Intellectual Property Press, Beijing, 2nd edition, 2005): Zhang Xiaodu, Substantial Requirements for Patent (Law Press, Beijing, 2002); Wei Yanliang, Studies on Patent Protection for Biotechnology (Intellectual Property Press, Beijing, 2004); and Liu Yinliang, Studies on Legal lssues for Biolechnology (Science Publishing House, Beijing, 2007).

\section{REFERENCES}

Arrow, Kenneth J. (1962), 'Economic Welfare and the Allocation of Resources for Invention, in the Rate and Direction of Inventive Activity', in Nelson, R.R., The Rate and Direction of Invention Activity: Economic and Social Factors, Cambridge, MA: (National Bureau of Economic Research) pp. 609-626.

Ashton, T.S. (1968), The Industrial Revolution, 1760-1830, Oxford: Oxford University Press.

Barton, J.H. (2006), 'Emerging Patent Issues in Genomic Diagnostics', Nature Biotechnology, Vol. 24, No. 8, 939-941.

Barton, J.H. and E.J. Emanuel (2005), 'The Patent-Based Pharmaceutical Development Process, Rationale, Problems, and Potential Reforms'. The Journal of the American Medical Association, 294 (16), 2075-2082.

Blakeney, M. (2009). 'Biotechnological Patenting and Innovation', in Prinz zu Waldeck und Pyrmont W., M.J. Adelmann, R. Brauneis, J. Drexl, and R. Nack (eds) (2009), Patents and Technological Progress in a Globalized World, Berlin Heidelberg: Springer-Berlag, p. 240.

Boehm K. and A. Silberston (1967), The British Patent System: Administration, Cambridge: Cambridge University Press.

Braga, C.A.P. (1990), 'The Developing Country Case For and Against Intellectual Property Protection,' in W.E. Siebeck (ed.), Strengthening Protection of Intellectual Property in Developing Couniries (112 World Bank Discussion Papers), pp. 69-87.

Burk, D.L. and Mark A. Lemley (2003), 'Policy Levers in Patent Law', Virginia Lanv Review, 89, 1575.

Chambers, J. (2003). 'Patent Eligibility of Biotechnological Inventions in the United States, Europe and Japan: How Much Patent Policy is Public Policy?' George Washington International Law Review, 34, p. 225.

CIPR (2002), Integrating Intellectual Property Rights and Development Policy, London: CIPR.

Coriat, B., F. Orsi and C. d'Almeida (2006), 'TRIPS and the International Public Health Controversies: Issues and Challenges', Indusirial and Corporate Change, 15 (6), 1033-62.

Dutton, H.I. (1984), The Patent System and Inventive Activity During the Industrial Revolution, 1750-1852, Manchester; Dover, NH: Manchester University Press.

Frew, S.E, R. Rezaie, S.M. Sammut, M. Ray, A.S. Daar and P. Singer (2007), 'India's health biotech sector at a crossroads', Nature Biotechnology, 25 (4), 415.

Grace, C. (2004), 'The Effect of Changing Intellectual Property on Pharmaceutical Industry Prospects in India and China: Considerations for Access to Medicines', Issues paper, London: DFID Health Resource Center.

Greenhalgh, C. and Mark Rogers (2007). 'The value of intellectual property rights to firms and society', Oxford Review of Economic Policy, 23 (4), 541-56. 
Grundmann, H.E. (1970), 'The Economic Arguments for Patents and their Validity for Developing Countries,' Indian Economic Journal, 19 (2), 198.

Heller, M.A. and R.S. Eisenberg (1998), 'Can Patents Deter Innovation? The Anticommons in Biomedical Research', Science, 280 (5364), 698-701, accessed: www.sciencemag.org/cgi /content/full/280/5364/698.

Landes, D.S. (1970), The Unbound Prometheus, Cambridge: Cambridge University Press.

Machlup, F. (1958), An Economic Review of the Patent System, Study No. 15 of the Subcommittee on Patents, Trademarks and Copyrights of the Committee on the Judiciary, U.S. Senate 85 th Congress, 2nd Session, Washington, pp. 79 - 80.

Mansfield, E. (1986) 'Patents and Innovation', Management Science, 32(2), 173-81.

Maskus, Keith (2003), 'Transfer of Technology and Technological Capacity Building, accessed: www.iprsonline.org/unctadictsd/bellagio/docs/Maskus_Bellagio2.pdf.

Quach, U., H. Thorsteinsdottir, J. Renihan, A. Bhath Z. Aesch, P. Singer, and A. Daar (2006), 'Biotechnology patenting takes off in developing countries', International Journal of Biotechnology, $8(1 / 2), 45$.

Outlines of National Intellectual Property Strategy (2008), Article 2 (7), 'Goals for the next five years', accessed: www.nipso.cn/gnwzscqxx/qtipdt/20080621_98086.asp.

Rezaie, R., S.E. Frew, S.M. Sammut, M.R. Maliakkal, A.S. Daar \& P. Singer (2008), 'Brazilian health biotech - fostering crosstalk between public and private sectors', Nature Biotechnology, $26(6), 637$.

Roger, Mark (1998), 'The Definition and Measurement of Innovation', Melbourne Instituse Working Paper No. 10/98, 5, accessed; www.melboumeinstitute.com/wp/wp1998n 10.pdf.

Schiff, E. (1971), Industrialization Without National Patents: The Netherlands, 1869-19/2, Switzerland, 1850-1907. Princeton University Press.

Schmookler, J. (1966), Invention and Economic Growth, Cambridge, MA: Harvard University Press.

Seguin; B., B. Hardy, P.A. Singer and A.S. Daar (2008), 'Genomic medicine and developing countries: creating a room of their own', Nature Rewiews/Genetics, 9, 487-493, 487.

SIPO Bureau of Planing and Development (2007), 'China accepted 4 million patent applications', Patent Statistics Report, 23, accessed: www.sipo.gov.cn/sipo/ztxx/zlxxjb/.

Stephen E. Siwik of Economists Incorporated (2005), 'Engines of Growth: Economic Contributions of the U.S. Intellectual Property Industries', Economists Incorporated, accessed: www.nbcuni.com/About_NBC_Universal/Intellectual_Property/pdf/Engines_of_Growth.pdf.

Straus, J. (2007), 'The Impact of the New World Order on Economic Development: The Role of the Intellectual Property Right System', European Review, 15 (1), 47-63.

Tang, Y.J. (2004), 'Chinese biotech industry on its way to innovation', ACHEMASIA Trend Report: Chinese Biotech Industry, ACHEMASIA, 6th International Exhibition-Congress on Chemical Engineering and Biotechnology, accessed: www.achemasia.de/data/achemasia_/tren d_report_10_e.htm. 